\title{
Extending green supply chain management activities to manufacturing small and medium enterprises in a developing economy
}

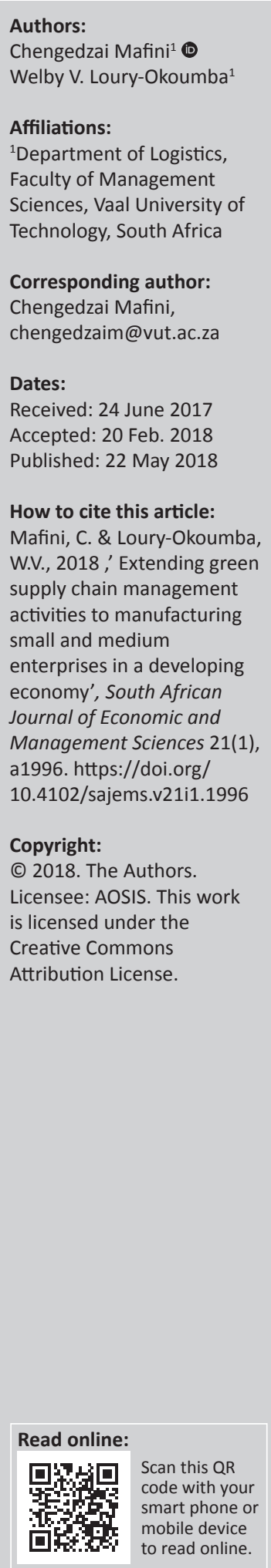

Background: The implementation of green supply chain management activities as a business strategy remains unfamiliar to many small and medium enterprises (SMEs) in developing countries such as South Africa.

Setting: Implementation of green supply chain management activities by South African SMEs is necessary, given both the high failure rate of such enterprises in the country and the proven ability of such activities to promote the success of businesses.

Aim: The aim of this study was to investigate the relationship between green supply chain management activities, operational performance and supply chain performance in manufacturing SMEs in South Africa.

Methods: Data were collected from 219 manufacturing SMEs operating within Gauteng. A confirmatory factor analysis was conducted to assess the psychometric properties of measurement scales. Hypotheses were tested using structural equation modelling.

Results: Four green supply chain management activities, namely green purchasing, reverse logistics, environmental collaboration with suppliers and green manufacturing, exerted a positive influence on operational performance. Environmental collaboration with suppliers exerted the highest influence on operational performance when compared to green purchasing, reverse logistics and green manufacturing. In turn, operational performance exerted a strong positive influence on supply chain performance.

Conclusion: The results of the study suggest that manufacturing SMEs in developing countries could benefit by adopting green supply chain management activities, with improvements being realised in terms of increases in both operational and supply chain performance.

\section{Introduction}

Small and medium enterprises (SMEs) are widely recognised as an important contributor to economic development in most countries throughout the world. The economic impact is most noticeable in areas such as employment creation and wealth creation (Baumann et al. 2013). In the context of South Africa, SMEs have been acknowledged to account for roughly $52 \%$ to $57 \%$ of South Africa's gross domestic product (GDP) and poured in an estimated $61 \%$ of employment generation in the past few years (SME South Africa 2017). However, pressure has mounted on SMEs to reengineer their business activities and processes in line with global developments (Kraus et al. 2012). This pressure stems from the high failure rate of most SMEs, part of which is attributable to their preoccupation with outdated business models. As mentioned by Vivier (2013), SMEs cannot afford to continue moving along conventional business trajectories, but need to innovate and realign their strategies in line with global currents. This is experienced more in South Africa, where the SME failure rate is very high, with most business start-ups closing down within less than 5 years of existence (Cant, Erdis \& Sephapo 2014).

As mentioned above, SMEs intending to overcome the unpredictable dynamics in the global marketplace of today are under pressure to adopt and implement more effective business models. Green supply chain management (GSCM) has emerged as one of the most topical emergent business best practices, perhaps based on its microeconomic and macroeconomic significance (Geng, Mansouri \& Aktas 2017). Implementation of GSCM activities has been identified by a number of authors (Govindan et al. 2014; Hsu et al. 2013; Thiell et al. 2011; Williams \& Schaefer 2013) as one of the innovative business strategies that can enable businesses such as SMEs to survive and succeed in their operations. As suggested by Spence and Painter-Morland (2010), 
environmental awareness and concerns across most business spectrums have become an important topic in the modern world. Businesses today are expected to be mindful of their environmental obligations towards a safer and more sustainable reduction of pollution activities (Hoskin 2011). This then calls for more environmentally driven supply chain activities among business enterprises, which has compelled large businesses to adhere to and comply with the global demands for better implementation of GSCM activities (Orlitzky, Siegel \& Waldman 2011). However, SMEs have been lagging behind in the implementation of such activities, despite their ability to stimulate economic growth (Bürgi 2010). The pressure to reform is greater on manufacturing SMEs, whose activities have a greater environmental impact than those in other industries, such as retail and services (Sunjka \& Emwanu 2015). It becomes important then to investigate how manufacturing SMEs can be motivated to explore innovative business strategies that benefit not only themselves but all stakeholders as well.

The aim of this study is to investigate the relationship between GSCM activities, operational performance and supply chain performance in manufacturing SMEs in South Africa. Specifically, the study is intended to address two objectives, namely (1) to determine the influence of GSCM implementation on operational performance and (2) to determine the influence of operational performance on supply chain performance. Despite the large body of literature on GSCM, it appears that most previous studies have focused their emphasis on large corporations while disregarding SMEs (Luthra et al. 2012). Moreover, since countries such as South Africa are still developing, and hence the levels of environmental mindfulness among SMEs in these countries may still be low, there is a need to conduct more studies on issues such as GSCM within such enterprises. Several studies (Coetzee \& Bean 2016; Craiggs 2012; Mvubu \& Naude 2016; Niemann, Kotze \& Adamo 2016) have investigated GSCM within various industries in South Africa. Among SMEs, evidence of previous studies on GSCM in SMEs in South Africa is available through Hoskin (2011), Ojo, Mbowa and Akinlabi (2014), Van Rensburg (2015) and Mafini and Muposhi (2017). However, none of these studies tested the relationship between GSCM activities, operational performance and supply chain performance in manufacturing SMEs. Still, given that SMEs are the most prominent form of businesses and have a greater economic impact than large businesses in developing economies (Chrysostome \& Molz 2014), continuous research is necessary to generate new information that supports their productivity and success. This study is intended to address these research gaps. The study is significant in that it can be used as a future reference source for GSCM research in SMEs. Owners and managers within SMEs in developing countries can also use the results of this study as a diagnostic tool when addressing operational and supply chain performance-related problems.

The remaining sections of this article are organised as follows. The next section is a brief review of literature on the research constructs. Thereafter, the conceptual framework is provided and hypotheses are formulated. The research methodology section follows next, succeeded by the research results and discussions. The article closes by highlighting the limitations and suggestions for future research, conclusions drawn and the managerial implications. Measurement scales used in the study are found in Appendix 1.

\section{Literature review}

This section briefly analyses literature on the constructs used in this study. These are GSCM activities, operational performance and supply chain performance.

\section{Green supply chain management activities}

Over the past years, businesses have become aware of the strategic importance and critical nature as well as the role of the environment in shaping today's competitive market (Lai, Wong \& Cheng 2010). This has subsequently driven manufacturing businesses to revise their corporate business strategies as well as core supply chain activities towards a greener environmental approach (Sarkis, Zhu \& Lai 2011). As such, GSCM is viewed as an extension of supply chain activities that focus on minimising the environmental impact of products throughout their life cycle, such as green design, resource saving, harmful material reduction and product recycle or reuse (Holt \& Ghobadian 2009). The core objective of GSCM is to eliminate or minimise harmful effects originating from operational activities such as extraction and acquisition of raw materials and use or disposal of products (Eltayeb, Zailani \& Ramayah 2011). According to Diabat and Govindan (2011), GSCM embodies a large number of activities such as green design, green sourcing and procurement, green operation and manufacturing, green distribution, and green logistics as well as marketing. A study by Lee, Kim and Choi (2012) identified green purchasing, eco-design and cooperation with customers as GSCM activities. Environment management, reverse logistics, environmental collaboration with suppliers and product recovery are among other activities singled out in a study by Diabat, Khodaverdi and Olfat (2013). This study reports on the results of four GSCM activities, namely green purchasing, reverse logistics, environmental collaboration with suppliers and green manufacturing. Another GSCM activity (green design) was eliminated from the study due to non-performing data in the confirmatory factor analysis. Scholars such as Wisner, Tan and Leong (2012) acknowledge that although GSCM is a multidimensional construct, those constructs considered in this study are the most relevant operational dimensions required by SMEs to sustain their competitive advantages.

\section{Green purchasing}

Green purchasing has been defined by Eltayeb, Zailani and Jayaraman (2010) as an environmentally oriented purchasing activity based on the purchase of products or materials that meet the concern of the environment in terms of reduction of 
wastage, promotion of recycling, reuse, resource reduction and substitution of materials. Supply chain management literature identifies several drivers of green purchasing. These include environmental collaboration, top management commitment, regulatory pressure, environmental investment and customer pressure (Yen \& Yen 2011). Social influence, environmental concerns, perceived seriousness of environmental problems, perceived effectiveness of environmental behaviour, perceived environmental responsibility and concern for self-image in environmental protection have also been identified as key antecedent factors to green purchasing (Sinnappan \& Rahman 2011). Other drivers of green purchasing include awareness about government actions and support, beliefs about product safety and use, beliefs about product friendliness to the environment and availability of product and product information (Kaufmann, Panni \& Orphanidou 2012).

\section{Reverse logistics}

According to Diabat et al. (2013), reverse logistics refers to the movement of products from the point of consumption to the business manufacturing sites. Reverse logistics has the objective of recycling, reusing, repairing or remanufacturing and careful disposal of products as well as materials (Das \& Chowdhury 2012). It is acknowledged that reverse logistics is a key contributor to ensuring customer after-sale satisfaction since its implementation leads to better optimisation of aftermarket processes such as recycling and proper waste disposal (Bernon, Rossi \& Cullen 2011). Khor et al. (2016) advance that the repair, remanufacturing and reconditioning of products and materials are precondition determinants of effective implementation of reverse logistics activities. Furthermore, the critical value resulting from executing reverse logistics has been well documented. Examples of such benefits include an increased business environmental image, cost reduction as well as sustainable customer satisfaction and aftersales services (Wong et al. 2012).

\section{Environmental collaboration with suppliers}

Environmental collaboration with suppliers can be defined as any form of formal or informal collaborative activity taking place between two or more parties with the objective of engaging in mutual exchanges to solve environmental problems (Crane 1998). Green et al. (2012) in their study on environmental collaboration and organisational performance established that supplier decisions that embark on environmental collaborations are based on factors such as a business' internal environment management and green information systems. In addition, Zhu, Sarkis and Lai (2008) advocate that sound collaboration among businesses ensures internal GSCM activities, which are vital in achieving better environmental performance. This singles out the core value attached to proper strategic alliance between business partners. In their study on environmental collaboration and business performance, Green et al. (2012) established that internal environmental management and green information systems are determinant factors of environmental collaboration with suppliers. These authors further suggest that effective and sound collaborative environmental activities with supplying businesses result in improved supplier selection. This indicates that businesses that are concerned about the environment ensure that their interactions with business partners reflect their concerns.

\section{Green manufacturing}

Green manufacturing is widely regarded as an emergent topic which has attracted attention because of its relevance and role in sustaining the environment (Reich-Weiser, Vijayaraghavan \& Dornfeld 2010). It refers to the ability of a business to adopt green strategies and techniques designed to reduce or minimise the negative effects of production processes on the ecosystem. It further involves the provision of products and procedures that require minimal consumption of hazardous materials and energy (Deif 2011). The implementation of green manufacturing processes enables businesses to become more conscious of their duty to protect the environment by redesigning their operation systems and restructuring their disposal strategies to adhere to environmental sustainability regulations (Mittal \& Sangwan 2014). Sezen and Cankaya (2013) argue that it is important that manufacturing businesses evolve their production strategies to be more environmentally driven by including the proper recycling of waste, efficient disposal of hazardous products and protection of the labour force, thereby providing a conducive working environment. This view is supported by Flammer (2013), who concluded that green manufacturing is a twofold approach which is aimed at not only protecting the ecosystem, but meeting societal and economic expectations as well.

\section{Operational performance}

In the world of business, the term 'performance' generally relates to the accomplishment of a given task as measured against predetermined standards of accuracy, cost, speed and completeness (Bennett, Lance \& Woehr 2014). Operational performance may be perceived as the degree to which a business is able to function within prescribed standards in specific areas of its operations and processes (Prajogo et al. 2012). Inman et al. (2010) conceptualise operational performance in terms of the ability of a business to do things better, faster, more efficiently and more cheaply. Traditionally, there were five operational performance measures that are generic to most forms of operations, namely speed, quality, flexibility, dependability and cost (Prajogo et al. 2012). However, more measures have to date been added to this list, with productivity, reduction of waste and compliance with regulations being among the most notable ones (Belekoukias, Garza-Reyes \& Kumar 2014). The widely-acclaimed Balanced Scorecard indicators, customer satisfaction, financial performance, internal processes and learning and growth, are also applicable to operational performance (Kaplan 2010). Other measures that have been applied in measuring operational performance include effectiveness, defect date, efficiency and value-added time ratio (Karim \& Arif-Uz-Zaman 2013). In a study 
conducted by Dora et al. (2013), productivity was measured using indicators such as inventory reduction, cycle time or lead time reduction, quality improvement and on time delivery. This shows that different researchers have developed and applied various indicators in the assessment of operational performance, depending on the context of their research. As suggested by Belekoukias et al. (2014), operational performance is important to businesses since it is a major indicator of the health and success of the business. In this study, operational performance was measured using a subjective scale anchored on the delivery of goods, inventory levels, wastage, quality, quantity of goods produced and capacity utilisation (Zhu et al. 2008).

\section{Supply chain performance}

Supply chain performance can be defined as the overall evaluation of an entire business's supply chain activities in terms of its effectiveness and efficiency (Akyuz \& Erkan 2010). Supply chain performance includes tangible products and materials as well as intangible aspects such as services and relationships (Akyuz \& Erkan 2010). A supply chain operating at an adequate level of its performance objectives is highlighted by performance outcomes such as sustainable cooperation among networks partners, which is characterised by seamless information sharing (Banomyong \& Supant 2011). One of the key indicators of a performing supply chain is its effective integration and flexibility of different supply chain units (Qrunfleh \& Tarafda 2014). As such, a proper integrated supply chain results in more improved information conveyed across the whole chain. This subsequently contributes to an increase of business performance through a reduction of inventory and delivery lead time (Qrunfleh \& Tarafdar 2014). Furthermore, Chang, Tsai and Hsu (2013) advance that partner relationships, information sharing and integration are important determinants of supply chain performance. This gives prominence to the strategic significance of supply chain performance in contributing to the success of a business.

\section{Conceptual framework and hypotheses development}

The conceptual framework presented in Figure 1 highlights the relationships under investigation. The framework consists of four predictor constructs, which are green purchasing, reverse logistics, environmental collaboration

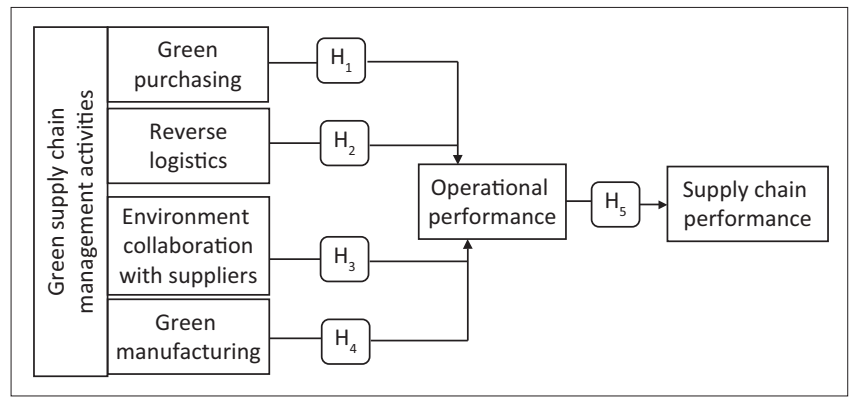

FIGURE 1: Conceptual framework linking green supply chain management activities to. with suppliers and green manufacturing. Operational performance is the mediating construct and the outcome construct is supply chain performance.

\section{Green purchasing and operational performance}

The importance and critical value of green purchasing has been well documented. Dubey et al. (2013) described green purchasing as a means of ensuring cleaner production technologies. Green purchasing is further regarded as critical in monitoring and controlling supplier performance objectives in terms of meeting the expectations and requirements of a business through its capability to provide materials that are in line with environment specifications (Eltayeb et al. 2011). As indicated by Dubey et al. (2013), effective employment of green purchasing strategies enables businesses to diligently manage their supplier environment performance, which can result in improved operational performance. Blome, Hollos and Paulraj (2014) further highlight that green purchasing is instrumental in achieving superior supplier performance, since it ensures that only quality material is processed. This serves as an indicator of the importance of green purchasing to environmental success. Thus, the following hypothesis is formulated:

$\mathbf{H}_{\mathbf{1}}$ : Green purchasing exerts a positive influence on operational performance in manufacturing SMEs.

\section{Reverse logistics and operational performance}

Significant improvement of waste management and disposal has been identified as a key enabler of operational performance (Khor et al. 2016). This is linked to environmental concerns by businesses, especially with regard to the proper handling of hazardous materials and products. Ye et al. (2013) mention that the application of reverse logistics typically results in improved buyer-supplier relationships across supply chain networks, highlighted by corporate social responsibility traits. Huscroft et al. (2013) advocate that adequate reverse logistics activities play a significant role in ensuring the return of products, which facilitates effective remanufacturing processes. Moreover, Eltayeb et al. (2011) suggest that the implementation of reverse logistics relates to operational performance outcomes in terms of cost reduction. Still, reverse logistics activities such as product repair, remanufacture, recondition, as well as recycling and proper good disposal, lead to increased sales and profitability (Khor et al. 2016). In light of these insights, the following hypothesis is put forward:

$\mathbf{H}_{2}$ : Reverse logistics has a positive influence on operational performance in manufacturing SMEs.

\section{Environmental collaboration with suppliers and operational performance}

Environmental collaboration with suppliers is an important enabler of green purchasing strategies that contribute effectively to an improved supplier environmental performance (Eltayeb et al. 2011). Adequate collaboration between businesses is critical in their ability to attain the required level of operational performance (Lai et al. 2011). 
Collaborative efforts among supply chain partners characterised by synergistic exchanges and engagement contribute swiftly to improved operation activities (Yang et al. 2013). Environmental collaboration with suppliers has further been regarded as essential in reducing information distortion between green supply chain members, which leads to better performance across the supply chain (Inman, Sale \& Green 2009). Therefore, the following hypothesis is advanced:

$\mathbf{H}_{3}$ : Environmental collaboration with suppliers has a positive influence on operational performance in manufacturing SMEs.

\section{Green manufacturing and operational performance}

Green manufacturing calls for a collaborative engagement between the stakeholders of a business to develop and implement sound operational activities which result in the improvement of both operational and environmental performance (Green et al. 2012). This is exhibited through reductions in cycle time, consumption of toxic raw material and negligent waste disposal. Wong et al. (2012) found that environmentally driven production has a positive and significant influence on operational performance. These authors further suggest that operations that are processoriented towards the environment enable businesses to produce and redesign their production capabilities to satisfy environment-related concerns. This ensures a decrease in pollution, which is linked to increases in both employee productivity and operational performance (Fu, Viard \& Zhang 2017; Zivin \& Neidell 2012). The greening of production processes allows firms to reduce their energy consumption and integrate more lean activities to minimise operations wastage and to speed up production, therefore contributing to the provision of organic products (Hajmohammad et al. 2013). This leads to the following hypothesis:

$\mathbf{H}_{4}$ : Green manufacturing has a positive influence on operational performance in manufacturing SMEs.

\section{Operational performance and supply chain performance}

According to Trkman et al. (2010), operational performance characterised by continuous information exchanges and alliance activities is a major determinant of supply chain performance. Sezhiyan, Page and Iskanius (2011) mention that operational performance outcomes anchored by logistics capabilities facilitate the improved performance of supply chain networks, which subsequently leads to competitive advantages. Govindan et al. (2015) further state that operational performance contributes to the sustainable success of a business's entire supply chain. Linton, Klassen and Jayaraman (2007) add that operational performance is a critical determinant of competitive advantage and better supply chain performance in fierce and highly competitive markets. In view of these views, the following hypothesis is suggested:

$\mathbf{H}_{5}$ : Operational performance has a positive influence on supply chain performance in manufacturing SMEs.

\section{Research methodology and data collection method}

\section{Instrumentation}

The study is quantitative in nature, making use of a structured survey questionnaire to collect data from the respondents. A quantitative study was chosen since the study was testing relationships between different constructs. Measurement scales were operationalised from previous studies. Green purchasing was measured using six items adapted from a study by Zhu et al. (2008). Reverse logistics was measured using six questions adapted from Ye et al. (2013) while environmental collaboration with suppliers was measured using five questions adapted from Vachon and Klassen (2006). Green manufacturing was measured using five items adapted from Zhu and Sarkis (2004). Operational performance was measured using six questions adapted from Zhu et al. (2008), and supply chain performance was measured using a 10 item-scale adapted from Li et al. (2005) and Li et al. (2006). Response options for the green purchasing, reverse logistics and green manufacturing scales were measured on a five-point Likert-type scale ranging from not considering it (1) to implementing successfully (5). For environmental collaboration with suppliers, operational performance and supply chain performance scales a different Likert-type scale, which was anchored by (1) not at all and (5) significant, was used.

\section{Sample and data collection}

The target population of the study was manufacturing SMEs across all industries in Gauteng, South Africa. The list of operating SMEs was obtained from the Gauteng Enterprise Propeller (GEP), SME databases from the municipalities in the region and from the Small Enterprises Development Agency (SEDA). According to SEDA (2016:13), the number of SMEs in Gauteng is 676 831. Using the Raosoft sample size calculator for this population, a 5\% margin of error and a $90 \%$ confidence interval and a $50 \%$ response distribution, the recommended sample size was 271 respondents. With this recommendation in mind, 400 questionnaires were initially distributed to SMEs. Out of these, 257 were returned, of which 38 were discarded because they had errors. Accordingly, 219 questionnaires were used in the final analysis, giving an acceptable response rate of $54 \%$.

The actual respondents consisted of either owners or managers of these SMEs. To ensure that SMEs from the various regions of the province were represented in the sample, the quota sampling technique was used. This involved splitting the SMEs into four distinct regions (north, south, east and west) of Gauteng and then randomly selecting SMEs from each region. Data were collected between January and May 2016 with the aid of two trained research assistants who were postgraduate students at a South African university of technology.

A summary of the demographic characteristics of the respondents indicated that $51.1 \%(n=112)$ of SMEs that 
participated in the study were sole proprietorships, $27.2 \%$ $(n=60)$ were partnerships and $21.7 \%(n=47)$ were private companies. With regard to the type of industry, $24.1 \%$ $(n=53)$ of the participating SMEs were in the agri-processing industry, $23.5 \%(n=52)$ were in the chemicals industry, $14.3 \%(n=31)$ were in the wood, paper and leather industry, $13.7 \%(n=30)$ operated within the metals industry, $13.3 \%$ $(n=30)$ were in the computer and electronics industry and $10.7 \%(n=23)$ were in the clothing and textiles industry. Furthermore, $42.9 \%(n=94)$ of SMEs were owned by white people, $35.6 \%(n=78)$ by black people, $17.5 \%(n=38)$ were owned by Indians or Asians and $4 \%(n=9)$ were owned by people of mixed race. In terms of SME representation by region, $22.1 \%(n=48)$ of the SMEs were drawn from northern Gauteng, 31.0\% (68) were drawn from the south, $19.4 \%(43)$ were drawn from the east and $27.5 \%(n=60)$ were drawn from the west.

\section{Data analysis}

After screening the returned questionnaires, the data collected from SMEs were captured on an Excel spreadsheet. Thereafter, the same data were analysed with the aid of the Statistical Package for Social Sciences (SPSS version 23.0) software to obtain the descriptive statistics, Cronbach's alpha values and correlations. For testing the psychometric properties of the measurement scales and testing the hypotheses, the Analysis of Moment Structures (AMOS version 23.0) statistical software was used.

\section{Ethical consideration}

In administering the questionnaire, various ethical considerations that include the respondents' right to confidentiality and anonymity, privacy or non-participation, informed consent, protection from harm and victimisation were followed. Respondents were not given any incentives for participating in the survey.

\section{Research results}

The results section focuses on the outcomes of the confirmatory factor analysis (CFA), hypothesis tests conducted through structural equation modelling (SEM) and the discussions. A CFA is a special form of factor analysis used to test whether the measures of a construct are consistent with the nature of that construct (Kline 2011). The SEM procedure is used to assess relationships between latent (unobservable) factors such as dependent and independent constructs (Bagozzi \& Yi 2012).

\section{Psychometric properties of measurement scales}

The analysis of psychometric properties of the measurement scales was conducted through a CFA to ascertain the reliability, validity and model fit of the constructs. The results of the CFA analysis are presented in Table 1.

As shown in Table 1, all five constructs under consideration in this study were reliable, since Cronbach's alpha values were
TABLE 1: Psychometric properties of measurement scales

\begin{tabular}{|c|c|c|c|c|c|c|}
\hline $\begin{array}{l}\text { Research constructs } \\
\text { or measures }\end{array}$ & $\begin{array}{l}\text { Item-total } \\
\text { correlations }\end{array}$ & $\begin{array}{l}\text { Factor } \\
\text { loadings }\end{array}$ & $\alpha$ & AVE & $\overline{\mathbf{x}}$ & $S D$ \\
\hline \multicolumn{7}{|l|}{ Green purchasing } \\
\hline GP1 & 0.54 & 0.56 & - & - & - & - \\
\hline GP2 & 0.61 & 0.74 & - & - & - & - \\
\hline GP3 & 0.67 & 0.75 & 0.81 & 0.46 & 3.24 & 0.67 \\
\hline GP4 & 0.56 & 0.67 & - & - & - & - \\
\hline GP5 & 0.52 & 0.58 & - & - & - & - \\
\hline GP6 & 0.65 & 0.75 & - & - & - & - \\
\hline \multicolumn{7}{|l|}{ Reverse logistics } \\
\hline RL1 & 0.57 & 0.64 & - & - & - & - \\
\hline RL2 & 0.58 & 0.66 & - & - & - & - \\
\hline RL3 & 0.51 & 0.59 & - & - & - & - \\
\hline RL4 & 0.67 & 0.78 & 0.80 & 0.42 & 3.13 & 0.71 \\
\hline RL5 & 0.55 & 0.50 & - & - & - & - \\
\hline RL6 & 0.60 & 0.57 & - & - & - & - \\
\hline \multicolumn{7}{|c|}{ Environmental collaboration with suppliers } \\
\hline ECS1 & 0.67 & 0.71 & - & - & - & - \\
\hline ECS2 & 0.64 & 0.70 & 0.72 & 0.46 & 3.81 & 1.06 \\
\hline ECS3 & 0.68 & 0.70 & - & - & - & - \\
\hline ECS4 & 0.52 & 0.54 & - & - & - & - \\
\hline ECS5 & 0.69 & 0.73 & - & - & - & - \\
\hline \multicolumn{7}{|c|}{ Green manufacturing } \\
\hline GM1 & 0.57 & 0.53 & - & - & - & - \\
\hline GM2 & 0.53 & 0.57 & 0.83 & 0.32 & 3.21 & 0.94 \\
\hline GM3 & 0.60 & 0.62 & - & - & - & - \\
\hline GM4 & 0.53 & 0.60 & - & - & - & - \\
\hline GM5 & 0.50 & 0.54 & - & - & - & - \\
\hline \multicolumn{7}{|c|}{ Operational performance } \\
\hline OP1 & 0.65 & 0.77 & - & - & - & - \\
\hline OP2 & 0.60 & 0.69 & - & - & - & - \\
\hline OP3 & 0.67 & 0.68 & - & - & - & - \\
\hline OP4 & 0.56 & 0.51 & 0.78 & 0.40 & 3.02 & 0.95 \\
\hline OP5 & 0.50 & 0.53 & - & - & - & - \\
\hline OP6 & 0.57 & 0.59 & - & - & - & - \\
\hline \multicolumn{7}{|c|}{ Supply chain performance } \\
\hline SCP1 & 0.57 & 0.61 & - & - & - & - \\
\hline SCP2 & 0.62 & 0.66 & - & - & - & - \\
\hline SCP3 & 0.60 & 0.58 & - & - & - & - \\
\hline SCP4 & 0.55 & 0.59 & - & - & - & - \\
\hline SCP5 & 0.65 & 0.74 & - & - & - & - \\
\hline SCP6 & 0.69 & 0.76 & 0.86 & 0.44 & 3.54 & 1.23 \\
\hline SCP7 & 0.59 & 0.64 & - & - & - & - \\
\hline SCP8 & 0.62 & 0.68 & - & - & - & - \\
\hline SCP9 & 0.57 & 0.60 & - & - & - & - \\
\hline SCP10 & 0.69 & 0.71 & - & - & - & - \\
\hline
\end{tabular}

$\alpha$, Cronbach's alpha; AVE, average variance extracted; $\bar{x}$, Mean; SD, standard deviation.

greater than the minimum threshold of 0.7 suggested by Nunnally (1978). Scale purification was conducted using item-total correlation values. As shown in in Table 1, all itemtotal correlation values were greater than the recommended minimum value of 0.3 (Field 2005), which further demonstrates that scale reliability was satisfactory in this study. Three types of validity were ascertained in this study. The first is face validity, which was ascertained through a review of the questionnaire by three academics whose research interests lie within supply chain management. Suggestions from these academics were considered and factored into the questionnaire. The second type of validity considered in the study is content validity, which was ascertained by pilottesting the questionnaire using a conveniently selected sample 
of 30 SMEs. These SMEs were subsequently excluded from the final survey. Using the feedback obtained from the pilot study, the questionnaire was modified to make it clearer. The third validity determined in this study is construct validity, which was measured through its two variants, namely convergent and discriminant validity. Convergent validity was satisfactory, since factor loadings for all items within the measurement scales surpassed the 0.5 minimum threshold suggested by Hair et al. (2006). Convergent validity was also satisfactory, since average variance extracted (AVE) values for five of the constructs exceeded the minimum threshold of 0.4 suggested by Anderson and Gerbing (1988), with the exception of green manufacturing whose AVE score was below the required threshold of 0.4 . However, the green purchasing factor was still retained in the study, since all of its factor loadings were above the recommended minimum value of 0.5 and the scale reliability was acceptable (Borsboom, Mellenbergh \& Van Heerden 2004). To measure discriminant validity, correlations between the constructs were used. According to Fornell and Larker (1981), correlation values less than 0.85 depict that discriminant validity exists between the scales since the constructs do not overlap each other and are measuring different things. The results of the correlation analysis are shown in Table 2.

As shown in Table 2, correlations between all constructs were positive, ranging between $r=0.112$ and $r=0.737$. This reveals that discriminant validity within the scales was satisfactory. In addition, these results show that constructs under consideration in this study are positively associated such that they fluctuate by either increasing or decreasing together. The strongest association was observed between environmental collaboration with suppliers and supply chain performance $(r=0.737)$. Overall, the results after testing indicate that all measurement scales eventually used in the study were both valid and reliable.

It has to be mentioned that one of the initial constructs (green design) was eliminated in the CFA. Although the green design construct initially had four scale items, two of them had item-total correlations below 0.3 and factor loadings below 0.5 and the Cronbach's alpha value of that scale was 0.42 , even after scale purification; hence the decision to purge the construct from the study.

Mean scores for all constructs (Table 1) in the measurement scale ranged between 3.02 and 3.81. The mean score values

TABLE 2: Correlations between constructs.

\begin{tabular}{|c|c|c|c|c|c|c|}
\hline Constructs & GP & RL & ECS & GM & OP & SCP \\
\hline Green purchasing (GP) & 1.000 & $0.254^{*}$ & - & - & - & - \\
\hline Reverse logistics (RL) & $0.286 *$ & 1.000 & - & - & - & - \\
\hline $\begin{array}{l}\text { Environmental collaboration } \\
\text { with suppliers (ECS) }\end{array}$ & $0.461^{*}$ & $0.503^{*}$ & 1.000 & - & - & - \\
\hline Green manufacturing (GM) & 0.433 & $0.178^{*}$ & $0.255^{*}$ & 1.000 & - & - \\
\hline $\begin{array}{l}\text { Operational } \\
\text { performance (OP) }\end{array}$ & $0.404^{*}$ & $0.323^{*}$ & $0.112 *$ & $0.368 *$ & 1.000 & - \\
\hline $\begin{array}{l}\text { Supply chain performance } \\
\text { (SCP) }\end{array}$ & $0.609 *$ & $0.552 *$ & $0.737 *$ & $0.500 *$ & $0.731 *$ & 1.000 \\
\hline
\end{tabular}

*, Correlation is significant at the 0.01 level (two-tailed). for green purchasing $(\bar{x}=3.24)$ and reverse logistics $(\bar{x}=3.13)$ depict that SMEs were currently considering implementing these activities. The mean score value for environmental collaboration with suppliers $(\bar{x}=3.81)$ demonstrates a relatively significant involvement in this activity by SMEs. For green manufacturing, the mean score was 3.02, showing that SMEs were currently considering implementing it. The mean score value for operational performance $(\bar{x}=3.02)$ illustrates that SMEs had to some degree managed to achieve the operational performance indicators measured in the scale. The mean score value $(\bar{x}=3.54)$ calculated for supply chain performance shows that SMEs had significantly achieved the supply chain performance indicators measured in the scale. Standard deviations for the scales ranged between 0.67 and 1.23. The fact that these values are low portrays that data points for all scales were clustered closely around their respective means, which reduces any uncertainties in the results of the study and makes them more authentic.

\section{Model fit analysis}

As recommended by Anderson and Gerbing (1988), model fit must be tested to determine how well both the CFA and SEM models fit the observed data. Schreiber et al. (2006) suggest that in order to meet the level of acceptability, the chi-square (CMIN/DF) value must be confined between 1 and 3. Further to that are values of the goodness of fit index (GFI), comparative fit index (CFI), incremental fit index (IFI), and Tucker-Lewis index (TLI), which should be equal to or greater than 0.90 in order to be acceptable (Bollen 1990; Hu \& Bentler 1995). Moreover, in order to be accepted, the root mean square error of approximation (RMSEA) must be equal to or less than 0.08 (Browne \& Cudeck 1993). The results for model fit analysis are presented in Table 3.

The results of the model fit for both the CFA and the SEM (Table 3) show that all model fit indices were satisfactory. This confirms that there was acceptable fit between both models and the underlying data structures.

\section{Testing the hypotheses}

Hypotheses were tested using the SEM procedure technique. The results are reported in Table 4 .

An analysis of the results of the hypotheses tests (Table 4) indicates that the beta coefficients for all the hypotheses were

TABLE 3: Model fit statistics.

\begin{tabular}{|c|c|c|c|}
\hline Model fit indices & $\begin{array}{l}\text { Acceptable fit } \\
\text { indices }\end{array}$ & $\begin{array}{l}\text { CFA (Measurement } \\
\text { model) }\end{array}$ & $\begin{array}{l}\text { SEM (Structural } \\
\text { model) }\end{array}$ \\
\hline $\begin{array}{l}\text { Chi-square or degree of } \\
\text { freedom }(d / f)\end{array}$ & $<3.00$ & 2.014 & 1.732 \\
\hline Goodness of fit index (GFI) & $>0.90$ & 0.911 & 0.920 \\
\hline Comparative fit index (CFI) & $>0.90$ & 0.900 & 0.954 \\
\hline Incremental fit index (IFI) & $>0.90$ & 0.963 & 0.943 \\
\hline Tucker-Lewis index (TLI) & $>0.90$ & 0.931 & 0.972 \\
\hline $\begin{array}{l}\text { Root mean square error of } \\
\text { approximation (RMSEA) }\end{array}$ & $<0.08$ & 0.072 & 0.066 \\
\hline
\end{tabular}

CFA, confirmatory factor analysis; SEM, structural equation modelling. 
TABLE 4: Hypotheses tests results.

\begin{tabular}{|c|c|c|c|c|c|}
\hline Proposed relationships & Hypothesis & Beta coefficient & $p$ & $t$ & Decision \\
\hline Green purchasing $\rightarrow$ operational performance & $\mathrm{H}_{1}$ & 0.654 & 0.007 & 2.445 & Accepted \\
\hline Reverse logistics $\rightarrow$ operational performance & $\mathrm{H}_{2}$ & 0.612 & 0.008 & 2.392 & Accepted \\
\hline Environmental collaboration with suppliers $\rightarrow$ operational performance & $\mathrm{H}_{3}$ & 0.781 & 0.000 & 3.315 & Accepted \\
\hline Green manufacturing $\rightarrow$ operational performance & $\mathrm{H}_{4}$ & 0.433 & 0.000 & 3.624 & Accepted \\
\hline Operational performance $\rightarrow$ supply chain performance & $\mathrm{H}_{5}$ & 0.762 & 0.005 & 2.562 & Accepted \\
\hline
\end{tabular}

*, Significance level $<0.01$

statistically significant at a level of at least $p<0.01$. Thus, all five hypotheses put forward in this study were accepted.

\section{Discussion}

The first hypothesis $\left(\mathrm{H}_{1}\right)$ proposed that green purchasing exerts a positive influence on operational performance. This hypothesis was accepted because there was a positive and significant relationship ( $\beta=0.654 ; p=0.007 ; t=2.445)$ between green purchasing and operational performance. This result implies that implementation of green purchasing by manufacturing SMEs predicts their operational performance. This result is supported by a previous study by Bjorklund (2010), which established that green purchasing contributes to waste and hazardous product reduction. This results in improved adherence to environmental regulations in terms of efficient operations and production processes. Dubey et al. (2013) add that implementation of green purchasing promotes the implementation of eco-friendly operational strategies, which again correlates with sound and safe operational outcomes. Furthermore, green purchasing has been found to be a key tool designed at improving operational performance through lowering production costs and sustaining the reduction of pollution (Green et al. 2012). In line with these results, manufacturing SMEs will be able to succeed in their operations when they adopt green purchasing strategies.

The second hypothesis $\left(\mathrm{H}_{2}\right)$ proposed a positive relationship between reverse logistics and operational performance. This relationship was supported and accepted because a positive and significant relationship ( $\beta=0.612 ; p=0.008 ; t=2.395$ ) was observed between reverse logistics and operational performance. This result demonstrates that implementation of reverse logistics by manufacturing SMEs results in improved operational performance. This result has been echoed by El Korchi and Millet (2011), who found that reverse logistics results in competitive advantages through its role in enhancing operation capabilities. For instance, poor quality raw materials may be identified and returned to the supplier and exchanged for better quality ones, which results in better quality products. Moreover, systems and processes for facilitating tend to promote the effective utilisation of business resources in the production phase (Khor et al. 2016). This is because putting in place an effective chain of product returns enables the operations process to be leaner and facilitates better repair and recondition of defective goods (Yang, Hong \& Modi 2011). This improves the performance of the operations process by enhancing the repurchase value of the returned goods. In this manner, implementation of reverse logistics activities by manufacturing SMEs enhances the operational performance of their value chain.
The third hypothesis $\left(\mathrm{H}_{3}\right)$ proposed that there exists a positive relationship between environmental collaboration with suppliers and operational performance. This hypothesis was accepted, since the relationship between environmental collaboration with suppliers was positive and significant $(\beta=0.781 ; p=0.000 ; t=3.315)$. This result demonstrates that operational performance will improve when manufacturing SMEs collaborate with their suppliers and form long-lasting relationships. This result resonates with a study by Yang et al. (2013), which stressed that collaborative engagement between businesses and suppliers is important in improving operational performance. Yang et al. (2013) reiterate that collaborative efforts between businesses and suppliers aid their combined ability to share environmental risks and problem-solving expertise, which is vital in leveraging competitive advantage. Luo et al. (2014) further add that environmental collaboration efforts between businesses contribute to achieving operational performance objectives. Accordingly, environmental collaboration with suppliers in manufacturing SMEs contributes significantly to the attainment of their operational objectives.

The fourth hypothesis (H4) proposed that there is a positive relationship between green manufacturing and operational performance. This hypothesis was accepted, since there was a positive and significant relationship $(\beta=0.433 ; p=0.000 ; t=$ 3.624 ) between the two constructs. This result implies that operational performance is likely to be higher in SMEs that have implemented green manufacturing. This result is synchronous with a study conducted by Dubey, Gunasekaran and Ali (2015), which concluded that the implementation of green manufacturing activities increases the efficiency of operations processes. This, in turn, enables businesses to improve their operational performance in terms of waste and pollution reduction as well as shorter life cycles of products. In another study by Lai and Wong (2012), environmentally driven production exerted a positive influence on operational performance in businesses. This was attributed to decreased expenditure realised through the implementation of lean production activities such as recycling, recuperation and the reuse of component parts and other materials critical in the provision of quality products. The results of the current study, therefore, showcase the adherence by manufacturing SMEs to their corporate social responsibility to the environment and their willingness to adopt green activities to reduce the negative effects of negligent manufacturing activities on the ecosystem (Paul, Bhole \& Chaudhari 2014).

The fifth hypothesis $\left(\mathrm{H}_{5}\right)$ proposed that there is a positive relationship between operational performance and supply 
chain performance. This hypothesis was accepted because a positive and significant relationship $(\beta=0.762 ; p=0.005$; $t=2.562$ ) was observed between the two constructs. This result illustrates that higher operational performance by a manufacturing SME leads to superior performance of the supply chain in which that SME operates. The results of this study correlate with a study by Trkman et al. (2010), which concluded that proper operational performance ensures that the supply chain of a business is able to meet the demands and expectations of customers. Furthermore, Jakhar (2015) posits that business enterprises that can improve their operational performance are more likely able to minimise their operation costs and to boost the effectiveness of the whole supply chain. Thus, manufacturing SME supply chains are likely to improve significantly whenever SMEs can sustain their operational performance.

\section{Limitations and suggestions for further research}

The study is limited in that data were collected from SMEs based in Gauteng only. In line with this, future studies could be conducted in other provinces, which is likely to provide the results of the study within a broader context. The other limitation of the study pertains to the inclusion of SMEs from various industries without catering for the heterogeneity within these different industries. In view of this, future studies could be conducted in specific SME industries, such that the results thereof will have a more defined context. Another limitation is the restriction of the study to only four GSCM activities, since green design was eliminated in the CFA. This provides opportunities to conduct the study again and include green design and any other GSCM activities that were not included in this study as this will provide more holistic results. In the same vein, future studies could include other dimensions of organisational performance that were excluded in this study, such as environmental, social and economic performance. A mixed method approach could be adopted in future studies as it enables the capturing of both objective (quantitative) and subjective (qualitative) views of respondents to provide a more comprehensive set of results.

\section{Conclusion and managerial implications}

The aim of this study was to investigate the relationship between GSCM activities, operational performance and supply chain performance in manufacturing SMEs. All five hypotheses formulated in the study were accepted. The study confirms the view that implementation of GSCM activities, namely green purchasing, reverse logistics, environmental collaboration with suppliers and green manufacturing, positively contributes to operational performance in manufacturing SMEs. The study further concludes that operational performance in manufacturing SMEs in South Africa positively influences supply chain performance. In this manner, the study provides validation of similar research results from other environments to the
South African manufacturing SME sector, where such a study had not been conducted before. The study therefore constitutes a reference source for future researchers on GSCM in similar environments.

To managers in manufacturing SMEs, implementation of GSCM activities is key to increasing both operational and supply chain performance. Likewise, the inability to implement GSCM activities in manufacturing SMEs could account for some of the challenges related to both operational and supply chain performance. When applying GSCM activities, more emphasis should be placed on collaborating with suppliers, which exerts a greater influence on operational performance than do green purchasing, reverse logistics and green manufacturing. To improve the implementation of GSCM activities in manufacturing SMEs, state of the art technology solutions should be put in place. Utilisation of such solutions may offer various paybacks such as data accuracy, easy integration with other tools and reduction in paperwork, which facilitates better sustainability. Reductions in packaging costs through the use of recyclable plastic materials in place of wood and paper-based materials could lead to the decline in carbon production, making these enterprises more environmentally friendly. The periodic maintenance of fleet vehicles as well as production equipment is likely to improve their costeffectiveness through reductions in the use of energy (fuel and electricity) and emissions. The methodical management of returned goods through the repair of both damaged and unwanted products in order to restore them to their original form and then resending them to the market can lead to improved financial returns. It is further important that the concept of GSCM be sold to the entire workforce in order to increase awareness within the business. In this regard, regular training and development programmes aimed specifically at promoting environmental awareness should be implemented to enable all human resources to understand the roles they have to play. A budget should be set aside for implementing the GSCM programme, so that financial resources can be provided when needed.

\section{Acknowledgements}

The authors would like to thank the Faculty of Management Sciences at Vaal University of Technology for providing the resources used in undertaking this study. The research was funded by the Faculty of Management Sciences at Vaal University of Technology.

\section{Competing interests}

The authors declare that they have no financial or personal relationships that may have inappropriately influenced them in writing this article.

\section{Authors' contributions}

W.V.L.-O. collected the data and conducted the review of literature. C.M. compiled the sections of the article. 


\section{References}

Akyuz, G.A. \& Erkan, T.E., 2010, 'Supply chain performance measurement: A literature review', International Journal of Production Research 48(17), 5137-5155.

Anderson, J.C. \& Gerbing, D.W., 1988, 'Structural equation modeling in practice: A review and recommended two-step approach', Psychological Bulletin 103(3), 411-423. https://doi.org/10.1037/0033-2909.103.3.411

Bagozzi, R. \& Yi, Y., 2012, 'Specification, evaluation, and interpretation of structural equation models', Journal of the Academy of Marketing Science 40(1), 8-34. https://doi.org/10.1007/s11747-011-0278-x

Banomyong, R. \& Supatn, N., 2011, 'Developing a supply chain performance tool for SMEs in Thailand', Supply Chain Management: An International Journal 16(1) 1-31. https://doi.org/10.1108/13598541111103476

Baumann, P., Wickert, D., Spence, L.J.C. \& Scherer, A.G., 2013, 'Organising corporate social responsibility in small and large firms: Size matters', Journal of Business Ethics 115(4), 693-705. https://doi.org/10.1007/s10551-013-1827-7

Belekoukias, I., Garza-Reyes, J.A. \& Kumar, V., 2014, 'The impact of lean methods and tools on the operational performance of manufacturing organisations', International Journal of Production Research 52(18), 5346-5366. https://doi.org/ 10.1080/00207543.2014.903348

Bennett, W., Lance, C.E. \& Woehr, D.J., 2014, Performance measurement: Current perspectives and future challenges, Psychology Press, London.

Bernon, M., Rossi, S. \& Cullen, J., 2011, 'Retail reverse logistics: A call and grounding framework for research', International Journal of Physical Distribution \& Logistics Management 41(5), 484-510. https://doi.org/10.1108/09600031111138835

Bjorklund, M., 2010, 'Influence from the business environment on environmental purchasing-drivers and hinders of purchasing green transportation services', Journal of Purchasing \& Supply Management 17, 11-22. https://doi.org/10.1016/j. pursup.2010.04.002

Blome, C., Hollos, D. \& Paulraj, A., 2014, 'Green procurement and green supplier development: Antecedents and effects on supplier performance', International Journal of Production Research 52(1), 32-49. https://doi.org/10.1080/00207543. 2013.825748

Bollen, K.A., 1990, 'Overall fit in covariance structure models: Two types of sample size effects', Psychological Bulletin 107(2), 256-259. https://doi.org/10.1037/00332909.107.2.256

Borsboom, D., Mellenbergh, G.J. \& Van Heerden, J., 2004, 'The concept of validity', Psychological Review 111(4), 1061-1071. https://doi.org/10.1037/0033-295X. 111.4.1061

Browne, M.W. \& Cudeck, R., 1993, 'Alternative ways of assessing model fit', Sage Focus Editions 154, 136-136.

Bürgi, J., 2010, 'A comprehensive model for SMEs: Measuring the dynamic interplay of morality, environment and management systems: Towards continuous improvement', in M. Painter-Morland \& L.J. Spence (Eds.), Ethics in small and medium sized enterprises, pp. 147-171, Springer, Dordrecht.

Cant, M.C., Erdis, C. \& Sephapo, C.M., 2014, 'Business survival: The constraints experienced by South African SMEs in the financial sector', International Journal of Academic Research in Business and Social Sciences 4(10), 565-570. https://doi. org/10.6007/IJARBSS/v4-i10/1255

Chang, H.H., Tsai, Y.C. \& Hsu, T.C.H., 2013, 'E-procurement and supply chain performance', Supply Chain Management: An International Journal 18(1), 34-51. https://doi.org/10.1108/13598541311293168

Chrysostome, E.V. \& Molz, R., 2014, Building businesses in emerging and developing countries: Challenges and opportunities, Routledge, London.

Coetzee, N. \& Bean, W.L., 2016, 'A green profitability framework to quantify the impact of green supply chain management in South Africa', Journal of Transport and Supply Chain Management 10(1), 251-261. https://doi.org/10.4102/jtscm. v10i1.251

Craiggs, J., 2012, 'Maturity assessment of green supply chain management in the South African FMCG Industry', Bachelor's dissertation, Faculty of Engineering, Built Environment and Information Technology, University of Pretoria, South Africa, viewed 11 February 2018, from https://repository.up.ac.za/ handle/2263/21027

Crane, A., 1998, 'Exploring green alliances', Journal of Marketing Management 14, 559-579. https://doi.org/10.1362/026725798784867734

Das, K. \& Chowdhury, A.C., 2012, 'Designing a reverse logistics network for optimal collection, recovery and quality-based product-mix planning', Internationa Journal of Production Economics 135, 209-221. https://doi.org/10.1016/j.ijpe. 2011.07.010

Deif, A.M., 2011 'A system model for green manufacturing', Journal of Cleaner Production 19, 1553-1559. https://doi.org/10.1016/j.jclepro.2011.05.022

Diabat, A. \& Govindan, K., 2011, 'An analysis of the drivers affecting the implementation of green supply chain management resource', Conservation \& Recycling 55(6), 659-667. https://doi.org/10.1016/j.resconrec.2010.12.002

Diabat, A., Khodaverdi, R. \& Olfat, L., 2013, 'An exploration of green supply chain practices and performances in an automotive industry', International Journal of Advance Manufacturing Technology 68, 949-961. https://doi.org/10.1007/ s00170-013-4955-4

Dora, M., Kumar, M., Goubergen, D.V., Molnar, A. \& Gellynck, X., 2013, 'Food quality management system: Reviewing assessment strategies and a feasibility study for European food small and medium-sized enterprises', Journal of Food Control 31, 607-616. https://doi.org/10.1016/j.foodcont.2012.12.006
Dubey, R., Bag, S., Ali, S.S. \& Venkatesh, V.G., 2013, 'Green purchasing is key to superior performance: An empirical study', International Journal of Procurement Management 6(2), 187-210.

Dubey, R., Gunasekaran, A. \& Ali, S.S., 2015, 'Exploring the relationship between leadership, operational practices, institutional pressures and environmental performance: A framework for green supply chain', International Journal of Production Economics 160, 120-132. https://doi.org/10.1504/IJPM.2013.052469

El Korchi, A. \& Millet, D., 2011, 'Designing a sustainable reverse logistics channel: The 18 generic structures framework', Journal of Cleaner Production 19(6-7), 588597. https://doi.org/10.1016/j.jclepro.2010.11.013

Eltayeb, T.K., Zailani, S. \& Jayaraman, K., 2010, 'The examination on the drivers for green purchasing adoption among EMS 14001 certified companies in Malaysia', Journal of Manufacturing Technology Management 21(2), 206-225. https://doi. org/10.1108/17410381011014378

Eltayeb, T.K., Zailani, S. \& Ramayah, T., 2011, 'Green supply chain initiatives among certified companies in Malaysia and environmental sustainability: Investigating the outcomes', Resources, Conservation \& Recycling 55(5), 495-506. https://doi. org/10.1016/j.resconrec.2010.09.003

Field, A., 2005, Discovering statistics using SPSS, 2nd edn., Sage, London.

Flammer, C., 2013, 'Corporate social responsibility and shareholder reaction: The environmental awareness of investors', Academy of Management Journal 56(3), 758-781. https://doi.org/10.5465/amj.2011.0744

Fornell, C. \& Larcker, D.F., 1981, 'Evaluating structural equation models with unobservable variables and measurement error', Journal of Marketing Research 18(1), 39-50. https://doi.org/10.2307/3151312

Fu, S., Viard, V.B. \& Zhang, P., 2017, 'Air quality and manufacturing firm productivity: Comprehensive evidence from China', Munich Personal RePEc Archive Paper No. 78914, viewed 09 February 2018, from https://mpra.ub.uni-muenchen. de/78914/1/MPRA_paper_78914.pdf

Geng, R., Mansouri, S.A. \& Aktas, E., 2017, 'The relationship between green supply chain management and performance: A meta-analysis of empirical evidences in Asian emerging economies', International Journal of Production Economics 183, 245-258. https://doi.org/10.1016/j.ijpe.2016.10.008

Govindan, K., Azevedo, S.G., Carvalho, H. \& Cruz-Machado, V., 2015, 'Lean, green and resilient practices influence on supply chain performance: Interpretive structural modeling approach', International Journal of Environmental Sciences \& Technology 12, 15-34. https://doi.org/10.1007/s13762-013-0409-7

Govindan, K., Kaliyan, M., Kannan, D. \& Haq, A.N., 2014, 'Barriers analysis for green supply chain management implementation in Indian industries using analytic hierarchy process', International Journal of Production Economics 147(Part B), 555-568. https://doi.org/10.1007/s13762-013-0409-7

Green, K.W., Zelbst, P.J., Bhadauria, V.S. \& Meacham, J., 2012, 'GSCM practices: Impact on performance', Supply Chain Management: An International Journal 17(3), 290-305.

Hair, J.F., Black, W.C., Babin, B.J., Anderson, R.E. \& Tatham, R.L., 2006, Multivariate data analysis, Auflage, Upper Saddle River, NJ.

Hajmohammad, S., Vachon, S., Klassen, R.D. \& Gavronski, I., 2013 'Reprint of lean management and supply management: Their role in green practices and management and supply management: Their role in green practices and
performance', Journal of Cleaner Production $56,86-93$. https://doi.org/10.1016/j. performance', Journ
jclepro.2013.06.038

Holt, D. \& Ghobadian, A., 2009, 'An empirical study of green supply chain management practices amongst UK manufacturers', Journal of Manufacturing Technology Management 20(7), 933-956. https://doi.org/10.1108/17410380910984212

Hoskin, P., 2011, 'Why business needs to green the supply chain', University of Auckland Business Review 13(1), 16-18.

Hsu, C.C., Tan, K.C., Zailani, S.H.M. \& Jayaraman, V., 2013, 'Supply chain drivers that foster the development of green initiatives in an emerging economy', International Journal of Operations \& Production Management 33(6), 656-688. https://doi. org/10.1108/IJOPM-10-2011-0401

Hu, L.T. \& Bentler, P.M., 1995, Evaluating model fit. Structural equation modeling: Concepts, issues, and applications, Sage, Thousand Oaks, CA.

Huscroft, J.R., Hazen, B.T., Hall, J.D., Skipper, J.B. \& Hanna, J.B., 2013, 'Reverse logistics: Past research, current management issues, and future directions', The International Journal of Logistics Management 24(3), 304-327. https://doi. org/10.1108/IJLM-04-2012-0024

Inman, R.A., Sale, M.L. \& Green, K.W. Jr., 2009, 'Analysis of the relationships among TOC use, TOC outcomes, and organisational performance', International Journal of Operations and Production Management 29(4), 341-356.

Inman, R.A., Sale, R.S., Green, K.W. \& Whitten, D., 2010, 'Agile manufacturing: Relation to JIT, operational performance and firm performance', Journal of Operations Management 29, 343-355. https://doi.org/10.1016/j.jom.2010.06.001

Jakhar, S.K., 2015, 'Performance evaluation and a flow allocation decision model for a sustainable supply chain of an apparel industry', Journal of Cleaner Production 87 391-413. https://doi.org/10.1016/j.jclepro.2014.09.089

Kaplan. R.S., 2010, Conceptual foundations of the balanced scorecard, Working Paper 10-074, Harvard Business School, Boston, MA.

Karim, A. \& Arif-Uz-Zaman, K., 2013, 'A methodology for effective implementation of lean strategies and its performance evaluation in manufacturing organizations', Business Process Management Journal 19(1), 169-196. https://doi.org/10.1108/ 14637151311294912

Kaufmann, H.R., Panni, M.F.A.K. \& Orphanidou, Y., 2012, 'Factors affecting consumers' green purchasing behavior: An integrated conceptual framework', Amfiteatru Economic 14(31), 50-69. 
Khor, K.S., Udin, Z.M., Ramayah, T. \& Hazen, B.T., 2016, 'Reverse logistics in Malaysia: The contingent role of institutional pressure', International Journal of Production Economics 175, 96-108. https://doi.org/10.1016/j.ijpe.2016.01.020

Kline, R., 2011, Principles and practice of structural equation modeling, 3rd edn., Guilford Press, New York, NY.

Kraus, S.J.P., Rigtering, C., Hughes, M. \& Hosman, V., 2012, 'Entrepreneurial orientation and the business performance of SMEs: A quantitative study from the Netherlands', Review of Managerial Science 6(2), 161-182.

Lai, K.H., Lun, V.Y., Wong, C.W. \& Cheng, T.C.E., 2011, 'Green shipping practices in the shipping industry: Conceptualisation, adoption, and implications', Resources, Conservation \& Recycling 55(6), 631-638. https://doi.org/10.1016/j.resconrec 2010.12.004

Lai, K.H., Wong, C.W. \& Cheng, T.C.E., 2010, 'Bundling digitized logistics activities and its performance implications', Industrial Marketing Management 39(2), 273-286. https://doi.org/10.1016/j.indmarman.2008.08.002

Lai, K.H. \& Wong, C.W.Y., 2012, 'Green logistics management and performance: Some empirical evidence from Chinese manufacturing exporters', Omega 40, 267-282. https://doi.org/10.1016/j.omega.2011.07.002

Lee, S.M., Kim, S.T., \& Choi, D., 2012, 'Green supply chain management and organisational performance', Industrial Management \& Data Systems 112(8), organisational performance', Industrial Management \&

Li, S., Ragu-Nathan, B., Ragu-Nathan, T.S. \& Rao, S.S., 2006, 'The impact of supply chain management practices on competitive advantage and organisationa performance', OMEGA 34(2), 107-124. https://doi.org/10.1016/j.omega.2004. 08.002

Li, S., Rao, S.S., Ragu-Nathan, T.S. \& Ragu-Nathan, B., 2005, 'Development and validation of a measurement instrument for studying supply chain management practices', Journal of Operations Management 23(6), 618-641. https://doi. org/10.1016/j.jom.2005.01.002

Linton, J.D., Klassen, R. \& Jayaraman, V., 2007, 'Sustainable supply chains: An introduction', Journal of Operations Management 25(6), 1075-1082. https://doi. org/10.1016/j.jom.2007.01.012

Luo, J., Chong, A.Y.L., Ngai, E.W.T. \& Liu, M.J., 2014, 'Green supply chain collaboration implementation in China: The mediating role of Guanxi', Transportation Research Part E 71, 98-110. https://doi.org/10.1016/j.tre.2014.09.005

Luthra, S., Garg, D., Kumar, S. \& Haleem, A, 2012, 'Implementation of the green supply chain management in manufacturing industry in India using interpretive structura modeling technique', BPR Technologia: A Journal of Science, Technology \& Management 1(1), 1-17.

Mafini, C. \& Muposhi, A., 2017, 'The impact of green supply chain management in small to medium enterprises: Cross-sectional evidence', Journal of Transport \& Supply Chain Management 11, a270.

Mittal, V.K. \& Sangwan, K.S., 2014, 'Prioritising drivers for green manufacturing: Environmental, social and economic perspectives', in 21st CIRP Conference on Life Cycle Engineering Procedia CIRP, vol. 15, Trondheim, Norway, 18-20 June, pp. $135-140$.

Mvubu, M. \& Naude, M.J., 2016, 'Green supply chain management constraints in the South African fast-moving consumer goods industry: A case study', Journal of Contemporary Management 13, 271-297.

Niemann, W., Kotze, T. \& Adamo, F., 2016, 'Drivers and barriers of green supply chain management implementation in the Mozambican manufacturing industry', Journal of Contemporary Management 13, 977-1013.

Nunnally, J., 1978, Psychometric methods, 2nd edn., McGraw-Hill, New York.

Ojo, E., Mbowa, C. \& Akinlabi, E.T., 2014, 'Barriers in implementing green supply chain management in construction industry', in Proceedings of the 2014 Internationa Conference on Industrial Engineering and Operations Management, Bali, 7-9 January, pp. 7-9.

Orlitzky, M., Siegel, D.S. \& Waldman, D.A., 2011, 'Strategic corporate social responsibility and environmental sustainability', Business \& Society 50(1), 6-27. https://doi.org/10.1177/0007650310394323

Paul, I.D., Bhole, G.P. \& Chaudhari, J.R., 2014, 'A review on green manufacturing: It's important, methodology and its application', Procedia Materials Science 6, 16441649. https://doi.org/10.1016/j.mspro.2014.07.149

Prajogo, D., Chowdhury, M., Yeung, A.C.L. \& Cheng, T.C.E., 2012, 'The relationship between supplier management and firm's operational performance: A multidimensional perspective', International Journal of Production Economics 136, 123-130. https://doi.org/10.1016/j.ijpe.2011.09.022

Qrunfleh, S. \& Tarafdar, M., 2014, 'Supply chain information systems strategy: Impacts on supply chain performance and firm performance', International Journal of Production Economics 147, 340-350. https://doi.org/10.1016/j.ijpe.2012.09.018

Reich-Weiser, C., Vijayaraghavan, A. \& Dornfeld, D., 2010, 'Appropriate use of green manufacturing frameworks', Escholarship, viewed 08 February 2018, from https:// escholarship.org/uc/item/10w7h9rb

Sarkis, J., Zhu, Q. \& Lai, K.H., 2011, 'An organisational theoretic review of green supply chain management literature', International Journal of Production Economics 130(1), 1-15. https://doi.org/10.1016/j.ijpe.2010.11.010

Schreiber, J.B., Nora, A., Stage, F.K., Barlow, E.A. \& King, J., 2006, 'Reporting structural equation modeling and confirmatory factor analysis results: A review', The
Journal of Educational Research 99(6), 323-338. https://doi.org/10.3200/ JOER.99.6.323-338

Sezen, B. \& Cankaya, S.Y., 2013, 'Effects of green manufacturing and eco-innovation on sustainability performance', in 9th International Strategic Management Conference, Procedia - Social and Behavioral Sciences, vol. 99, Riga, 27-29 June, pp. 154-163. https://doi.org/10.1016/j.sbspro.2013.10.481

Sezhiyan, D.M., Page, T. \& Iskanius, P., 2011, 'The impact of supply effort management, logistics capability, and supply chain management strategies on firm performance, International Journal of Electronic Transport 1(1), 26-44. https://doi.org/10.1504/ IJET.2011.043114

Sinnappan, P. \& Rahman, A.A., 2011, 'Antecedents of green purchasing behavior among Malaysian consumers', International Business Management 5(3), 129139. https://doi.org/10.3923/ibm.2011.129.139

Small Enterprises Development Agency (SEDA), 2016, The small, medium and micro enterprise sector of South Africa, Research Note 2016, No 1, viewed 04 February 2018, from http://www.seda.org.za/Publications/Publications/The $\% 20$ Small,\%20Medium $\% 20$ and $\% 20$ Micro\%20 Enterprise $\% 20$ Sector $\% 20$ of $\% 20$ South $\% 20$ Africa $\% 20$ Commissioned $\% 20$ by $\% 20$ Seda.pdf

SME South Africa, 2017, Why SA SMEs can expect better prospects in 2017, viewed 22 May 2017, from http://www.smesouthafrica.co.za/17024/3-reasons-SA-SMEscan-expect-a-better-2017/

Spence, L. \& Painter-Morland, M., 2010, Ethics in small and medium sized enterprises: A global commentary, Springer, New York.

Sunjka, B. \& Emwanu, B., 2015, 'Risk management in manufacturing SMEs in South Africa', in International Association for Management of Technology IAMOT 2015 Conference Proceedings, Cape Town, 8-11 June, pp. 1469-1486.

Thiell, M., Zuluaga, J.P.S., Montañez, J.P.M. \& Van Hoof, B., 2011, Green logistics: Global practices and their implementation in emerging markets. Green finance and sustainability: Environmentally-aware business models and technologies, University of Hong Kong, Hong Kong, pp. 334-357.

Trkman, P., McCormack, K., De Oliveira, M.P.V. \& Ladeira, M.B., 2010, 'The impact of business analytics on supply chain performance', Decision Support Systems 49(3), 318-327. https://doi.org/10.1016/j.dss.2010.03.007

Vachon, S. \& Klassen, R.D., 2006, 'Extending green practices across the supply chain: The impact of upstream and downstream integration', International Journal of Operations \& Production Management 26(7), 795-821. https://doi. org/10.1108/01443570610672248

Van Rensburg, S.L.J., 2015, 'A framework in green logistics for companies in South Africa', master's dissertation, University of South Africa, viewed 11 February 2018 from http://uir.unisa.ac.za/bitstream/handle/10500/18750/thesis jansen $\% 20$ van $\% 20$ rensburg_sl.pdf?sequence $=1$

Vivier, E., 2013, 'A tough line to work through: Ethical ambiguities in a South African SME', African Journal of Business Ethics 7(2), 68-78. https://doi.org/10.4103/1817 7417.123081

Williams, S. \& Schaefer, A., 2013, 'Small and medium-sized enterprises and sustainability: Managers' values and engagement with environmental and climate change issues', Business Strategy \& the Environment 22(3), 173-186. https://doi. org/10.1002/bse.1740

Wisner, J.D., Tan, K.C. \& Leong, G.K., 2012, Supply chain management: A balanced approach, 3rd edn., South-Western Cengage Learning, Mason, $\mathrm{OH}$.

Wong, C., Lai, K.H., Shang, K.C., Lu, C.S. \& Leung, T., 2012, 'Green operations and the moderating role of environmental management capability of suppliers on moderating role of environmental management capability of suppliers on 140(1), 283-294. https://doi.org/10.1016/j.ijpe.2011.08.031

Yang, C.S., Lu, C.S., Haider, J.J. \& Marlow, P.B., 2013, 'The effect of green supply chain management on green performance and firm competitiveness in the context of container shipping in Taiwan', Transportation Research Part E: Logistics \& Transportation Review 55, 55-73. https://doi.org/10.1016/j.tre.2013.03.005

Yang, M.G.M., Hong, P. \& Modi, S.B., 2011, 'Impact of lean manufacturing and environmental management on business performance: An empirical study of manufacturing firms', International Journal of Production Economics 129(2), 251261. https://doi.org/10.1016/j.ijpe.2010.10.017

Ye, F., Zhao, X., Prahinski, C. \& Li, Y., 2013, 'The impact of institutional pressures, top managers' posture and reverse logistics on performance: Evidence from China', International Journal of Production Economics 143(1), 132-143. https://doi. org/10.1016/j.ijpe.2012.12.021

Yen, Y. \& Yen, S., 2011, 'Top-management's role in green purchasing standards in hightech industrial firms', Journal of Business Research 65(7), 951-959. https://do. org/10.1016/j.jbusres.2011.05.002

Zivin, J.G. \& Neidell, M., 2012, 'The impact of pollution on worker productivity', American Economic Review 102(7), 3652-3673.

Zhu, Q. \& Sarkis, J., 2004, 'Relationships between operational practices and performance among early adopters of green supply chain management practices in Chinese manufacturing enterprises', Journal of Operations Management 22(3), 265-289. https://doi.org/10.1016/j.jom.2004.01.005

Zhu, Q., Sarkis, J. \& Lai, K.H., 2008, 'Confirmation of a measurement model for green supply chain management practices implementation', International Journal of Production Economics 111(2), 261-273. https://doi.org/10.1016/j.ijpe.2006. 11.029 


\section{Appendix 1}

Measurement scales used in the study

\section{Green purchasing}

Please indicate the extent to which you perceive that your business is implementing each of the following. (Five-point scale: $1=$ not considering it; 2 = planning to consider it; $3=$ considering it currently; 4 = initiating implementation; $5=$ implementing successfully).

- GP1: Eco labelling of products

- GP2: Cooperation with suppliers for environmental objectives

- GP3: Environmental audit of suppliers' internal management

- GP4: Suppliers' ISO 14001 (environmental management) certification

- GP5: Second-tier supplier environmentally friendly practice evaluation

- GP6: Providing design specification to suppliers that include environmental requirements for purchased item

\section{Reverse logistics}

Please indicate the extent of reverse logistics implementation in your business

(Five-point scale: 1 = not considering it; 2 = planning to consider it; 3 = considering it currently; 4 = initiating implementation; 5 = implementing successfully).

- RL1: Accepting product returns from customers

- RL2: Recalling products with quality problems

- RL3: Returning products to suppliers

- RL5: Recycling scrap and used items

- RL6: Repairing, recondition and remanufacture component parts from returned, defective, or damaged products

\section{Supplier environmental collaboration}

Please indicate the extent to which your business engaged in the following activities with its suppliers: Five-point scale: 1 = not at all; 2 = a little bit; 3 = to some degree; 4 = relatively significant; 5 = significant).

- ECS1: Achieved environmental goals collectively

- ECS2: Developed a mutual understanding of responsibilities regarding environmental performance

- ECS3: Worked together to reduce environmental impact of our activities

- ECS4: Conducted joint planning to anticipate and resolve environmental-related problems

- ECS5: Made joint decisions about ways to reduce overall environmental impact of our products

\section{Green manufacturing}

Please indicate the extent of reverse logistics implementation in your business

(Five-point scale: 1 = not considering it; 2 = planning to consider it; 3 = considering it currently; 4 = initiating implementation; 5 = implementing successfully).

- GM1: Cross-functional cooperation for environmental improvements

- GM2: Total quality environmental management

- GM3: Environmental compliance and auditing programs

- GM4: ISO14000 series certification

- GM5: Environmental management systems exist

\section{Operational performance}

Please indicate the extent to which you perceive that your business has achieved each of the following during the past year. (Five-point scale: 1 = not at all; 2 = a little bit; $3=$ to some degree; 4 = relatively significant; 5 = significant)

- OP1: Increase in the amount of goods delivered on time

- OP2: Decrease in inventory levels

- OP3: Decrease in scrap rate

- OP4: Increase in product quality

- OP5: Increase in product line

- OP6: Improved capacity utilisation

\section{Supply chain performance}

Please indicate the extent to which you perceive that your business has achieved each of the following during the past year. (Five-point scale: 1 = not at all; 2 = a little bit; 3 = to some degree; 4 = relatively significant; 5 = significant)

- SCP1: Ability to handle nonstandard orders

- SCP2: Ability to meet special customer specification requirements

- SCP3: Ability to produce products characterised by numerous features options, sizes and colors

- SCP4: Ability to rapidly adjust capacity so as to accelerate or decelerate production in response to changes in customer demand

- SCP5: Ability to rapidly introduce large numbers of product improvements variation

- SCP6: Ability to handle rapid introduction of new products

- SCP7: Fast customer response time

- SCP8: Characterised by a great amount of cross-over of the activities of our business and our trading partners

- SCP9: characterised by a high level of integration of information systems in our business

- SCP10: Short order-to-delivery cycle time 